\title{
KONTRIBUSI USAHA TANI BUAH NAGA TERHADAP TINGKAT PENDAPATAN KELUARGA DI NAGARI ARIPAN KECAMATAN $X$ KOTO SINGKARAK KABUPATEN SOLOK
}

\author{
Meri Karmila ${ }^{1}$ Dedi Hermon ${ }^{2}$ Iswandi $\mathbf{U}^{2}$ \\ Program Studi Pendidikan Geografi \\ JurusanGeografi Fakultas Ilmu Sosial Universitas Negeri Padang \\ Email:Meri.karmila3006@gmail.com
}

\begin{abstract}
Abstrak
Penelitian ini bertujuan untuk mengetahui kontribusi usaha tani buah naga terhadap tingkat pendapatan keluarga di Nagari Aripan Kecamatan X Koto Singkarak Kabupaten Solok berdasarkan faktor pendukung dan penghambat dalam usaha tani buah naga di Nagari Aripan. Jenis penelitian ini adalah deskriptif kuantitatif. Sampel penelitian adalah masyarakat yang bertanam buah naga dengan jumlah sampel 32 KK. Teknik pengumpulan data digunakan angket atau kuesioner, wawancara dan dokumentasi. Teknik analisis menggunakan rumus persentase. Hasil penelitian ini dapat disimpulkan bahwa kontribusi usaha tani buah naga terhadap pendapatan total rumah tangga adalah sebesar 52,81\%. Hal ini menunjukkan bahwa hasil usaha tani buah naga merupakan sumber pendapatan yang memberikan kontribusi yang cukup besar. Pendapatan usaha tani buah naga digunakan petani untuk memenuhi kebutuhan keluarga. Faktor pendukung usaha tani buah naga di Nagari Aripan Kecamatan X Koto Singkarak Kabupaten Solok adalah harga buah naga sangat tinggi di pasaran dan tenaga kerja mudah diperoleh di Nagari Aripan. Sementara itu faktor penghambat usaha tani buah naga di Nagari Aripan Kecamatan X Koto Singkarak Kabupaten Solok adalah modal usaha masih terbatas, keterbatasan pengetahuan, kurangnya informasi budidaya buah naga dari Dinas Pertanian.
\end{abstract}

Kata kunci : Kontribusi, Buah naga, Faktor pendukung dan penghambat.

\section{Abstract}

This study aims to determine the contribution of dragon fruit farming to the farmer income level of family income in Nagari Aripan Kecamatan X Koto Singkarak, Solok Regency based on supporting and inhibiting factors in dragon fruit farming in Nagari Aripan. This type of research is quantitative descriptive. The research sample was the community who planted dragon fruit with a sample of 32 families. Data collection techniques used on the research are questionnaires, interviews and documentation. Analysis technique used percentage formula. The results of this study can be concluded that the contribution of dragon fruit farming to total household income is $52.81 \%$. This shows that dragon fruit farming is a source of income which contributes quite large. The income of dragon fruit farming used by farmers to meet family needs. Supporting factors of dragon fruit farming in Nagari Aripan Kecamatan X Koto Singkarak Solok Regency is the price of dragon fruit is very high in the market and labor is easily obtained in Nagari Aripan. Meanwhile, the inhibiting factor of dragon fruit farming in Nagari Aripan Kecamatan X Koto Singkarak Solok Regency is limited business capital, limited knowledge, lack of information on dragon fruit cultivation from the Department of Agriculture.

Keywords: contribution, dragon fruit, supporting factor and inhibiting.

\footnotetext{
${ }^{1}$ Mahasiswa Program Studi Pendidikan Geografi untuk Wisuda Maret 2018

${ }^{2}$ Dosen Jurusan Geografi Fakultas Ilmu Sosial Universitas Negeri Padang, Pembimbing 1: Dr. Dedi

Hermon, M. P, Pembimbing 2: Dr. Iswandi U, S. Pd, M. Si
} 


\section{PENDAHULUAN}

$\begin{array}{ccc}\text { Di } & \text { Indonesia } & \text { pertanian } \\ \text { merupakan } & \text { tulang } & \text { punggung }\end{array}$
kehidupan, bahkan ada pendapat yang lebih tegas lagi mengatakan bahwa kemakmuran perekonomian tergantung pada kemakmuran pertanian dan meningkatkan pendapatan akan dan ditekankan pula pada peningkatan sektor pertanian (Bishop, 1979:28).

Pertanian merupakan suatu kegiatan pemanfaatan sumber daya hayati yang dilakukan manusia untuk mengahasilkan bahan pangan, bahan baku industri atau sumber energi serta untuk mengelola lingkungan hidupnya. Kegiatan pemanfaatan sumber daya hayati yang termasuk dalam pertanian biasa disebut sebagai budidaya tanaman atau bercocok tanam. Dalam pertanian ada suatu istilah "Usaha Tani" yaitu bagian inti dari pertanian karena menyangkut sekumpulan kegiatan yang dilakukan dalam budidaya. Petani adalah sebutan bagi mereka yang melakukan usaha tani. Pertanian dalam pengertian yang luas mencakup semua kegiatan yang melibatkan pemanfaatan makhluk hidup untuk kepentingan manusia.

Menurut Midgley (2000) kondisi sejahtera pada umumnya merujuk pada istilah kesejahteraan sosial sebagai kondisi terpenuhinya kebutuhan material dan non material. Dalam hal ini, kondisi kesejahteraan sosial diartikan sebagai kondisi kehidupan manusia yang aman dan bahagia karena kebutuhan dasar akan gizi, kesehatan, pendidikan, tempat tinggal dan pendapatan layak telah terpenuhi, serta terjadi ketika manusia memperoleh perlindungan dari resiko-resiko utama yang mengancam kehidupannya.

Mubyarto

mengemukakan bahwa usaha tani adalah himpunan sumber-sumber alam yang terdapat pada sektor pertanian itu diperlukan untuk produksi pertanian, tanah dan air, perbaikan-perbaikan yang telah dilakukan di atas tanah dan sebagainya, atau dapat dikatakan bahwa pemanfaatan tanah untuk kebutuhan hidup. Dalam meningkatkan usaha tani itu sendiri kita memerlukan kontribusi dalam usaha tani buah naga ini yaitu : Modal, luas lahan, bibit/benih, pupuk, curahan tenaga kerja.

Pendapatan menurut Mubyarto (1983) adalah jumlah keseluruhan pendapatan atau kekayaan keluarga (termasuk semua barang dan hewan peliharaan). Pendapatan pada prinsipnya dibagi tiga kelompok yang berpenghasilan tinggi, sedang dan rendah. Faktor - faktor yang mempengaruhi pendapatan adalah Jenis pekerjaan atau jabatan, pendidikan, masa kerja, jumlah anggota keluarga.

Saat sekarang ini para petani tidak terlalu berfokus pada penanaman tanaman keras ladang mereka karena pada saat sekarang ini banyak hasil perkebunan yang 
melonjak harga di pasaran seperti halnya pada buah naga yang menjadi sektor pertanian yang bisa membantu penghasilan petani.

Laju pertumbuhan Produk Domestik Regional Bruto (PDRB) atas dasar harga konstan selang waktu 5 tahun terakhir yaitu pada tahun 2012 - 2016 dilihat pada tabel 1 berikut:

Tabel 1 : Laju Pertumbuhan PDRB Atas Dasar Harga Konstan 2010 Menurut Lapangan Usaha di Kabupaten Solok (Persen) 2012/2016

\begin{tabular}{|l|c|c|c|c|c|}
\hline \multirow{2}{*}{ Kategori } & \multicolumn{5}{|c|}{ Tahun } \\
\cline { 2 - 6 } & 2012 & 2013 & 2014 & 2015 & 2016 \\
\hline Pertanian, Kehutanan dan Perikanan & 4,07 & 3,06 & 4,67 & 3,62 & 2,83 \\
\hline Pertambangan dan Pengalian & 8,4 & 6,63 & 6,47 & 2,12 & 4,82 \\
\hline Industri Pengolahan & 10,25 & 6,17 & 6,4 & 6,31 & 6,77 \\
\hline Pengadaan Listrik dan Gas & 6,08 & 5,08 & 13,35 & 4,5 & 10,5 \\
\hline $\begin{array}{l}\text { Pengadaan Air, Pengelolaan Sampah, } \\
\text { Limbah dan Daur Ulang }\end{array}$ & 5,65 & 9,54 & 4,04 & 2,65 & 2,37 \\
\hline Konstruksi & 9,93 & 11,14 & 6,24 & 6,77 & 6,86 \\
\hline $\begin{array}{l}\text { Perdagaan Besar dan Eceran; Reparasi } \\
\text { Mobil dan Sepeda Motor }\end{array}$ & 9,44 & 8,56 & 6,57 & 6,02 & 6,15 \\
\hline Transportasi dan Pergudangan & 6,74 & 4,24 & 5,71 & 8,52 & 7,44 \\
\hline $\begin{array}{l}\text { Penyediaan Akomodasi dan makan } \\
\text { minum }\end{array}$ & 6,51 & 4,18 & 4,43 & 7,1 & 9,57 \\
\hline Informasi dan Komunikasi & 12,48 & 11,88 & 11,69 & 9,94 & 9,22 \\
\hline Jasa Keuangan dan Asuransi & 9,08 & 7,23 & 3,3 & 3,15 & 6,74 \\
\hline Real Estate & 4,89 & 5,69 & 5,56 & 6 & 5,6 \\
\hline Jasa Perusahaan & 3,67 & 3,82 & 2,96 & 6,26 & 4,28 \\
\hline $\begin{array}{l}\text { Administrasi Pemerintahan, Pertahanan } \\
\text { dan Jaminan Sosial Wajib }\end{array}$ & 0,23 & 4,47 & 4,48 & 5,38 & 5,48 \\
\hline Jasa Pendidikan & 9,27 & 8,57 & 7,64 & 9,1 & 9,18 \\
\hline Jasa Kesehatan dan Kegiatan Sosial & 10,35 & 8,13 & 6,78 & 7,61 & 5,29 \\
\hline Jasa Lainnya & 4,85 & 5,49 & 4,69 & 3,14 & 7,81 \\
\hline \multicolumn{1}{|c|}{ Total PDRB } & 6,43 & 5,63 & 5,79 & 5,43 & 6,3 \\
\hline
\end{tabular}

Sumber: BPS Kabupaten Solok 2017

Tabel 1 di atas diperlihatkan laju pertumbuhan Produk Domestik Regional Bruto (PDRB) atas dasar harga konstan tahun 2012 sampai dengan tahun 2016. Disini terlihat dalam tabel bahwa tingkat laju pertumbuhan ekonomi pertanian, perhutanan dan perikanan pada tahun
2016 adalah sebesar 2,83 persen lebih rendah daripada tahun 2015 sebesar 3,62 persen.

Dalam usaha tanaman buah naga ini kebanyakan masyarakat di Nagari Aripan melakukan tanaman buah naga sebagai pekerjaan sampingannya. Dimana masyarakat yang melakukan 
tanaman buah naga ini mengaku bahwa usahanya sangat menguntungkan karena tanaman mudah diurus, modal terjangkau dan laku dijual kapan saja meskipun harganya cenderung tidak stabil. Namun dalam menjalankan usaha tani buah naga petani di Nagari Aripan Kecamatan X Koto Singkarak Kabupaten Solok pasti mengalami hambatan yang beragam yang selanjutnya akan berpengaruh terhadap kualitas dan banyak sedikitnya hasil produksi. Hambatan utamanya adalah modal karena para petani pada umumnya hanya mengandalkan modal sendiri.

Berbagai hambatan yang dihadapi oleh petani buah naga di Nagari Aripan dapat berpengaruh terhadap pendapatan usaha tani buah naga yang pada akhirnya berpengaruh terhadap pendapatan keluarga. Keuntungan yang dimiliki Nagari Aripan berupa lahan yang cukup luas untuk menjalankan usaha tani buah naga bisa menjadi faktor pendorong dalam pengembangan usaha tani sehingga hasil yang diproduksi bisa memuaskan dan dapat meningkatkan pendapatan keluarga mereka. Sedangkan hambatan-hambatan yang dihadapi para petani buah naga di Nagari Aripan bisa menjadi faktor penghambat dalam menjalankan usaha tani tersebut dan akan berpengaruh juga terhadap pendapatan.

Berdasarkan latar belakang, yang menjadi permasalahan dalam penelitian ini adalah berapa besar kontribusi usaha tani buah naga terhadap tingkat pendapatan keluarga di Nagari Aripan Kecamatan X Koto Singkarak Kabupaten Solok, Tujuan dari penelitian ini adalah mengetahui, menganalisa dan membahas tentang Faktor pendorong dan penghambat usaha tani buah naga terhadap pendapatan keluarga di Nagari Aripan Kecamatan X Koto Singkarak Kabupaten Solok dan Seberapa besar kontribusi usaha tani buah naga terhadap pendapatan keluarga buah naga di Nagari Aripan Kecamatan X Koto Singkarak Kabupaten Solok. Manfaat dalam penelitian ini yaitu menambah wawasan bagi peneliti sendiri serta mengetahui seberapa besar kontribusi tanaman buah naga terhadap pendapatan petani itu sendiri, Informasi bagi petani dan lembaga pemerintah terutama dinas perkebunan untuk lebih memperhatikan komoditas perkebunan terutama tanaman buah naga sehingga dapat meningkatkan hasil dan menambah pendapatan keluarga.

\section{METODE PENELITIAN}

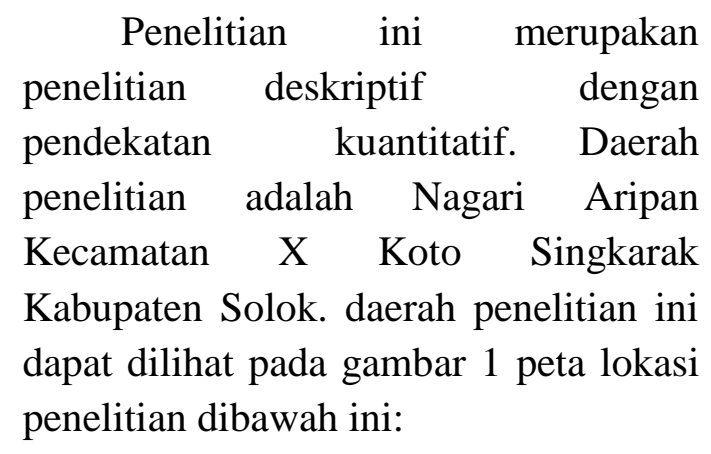




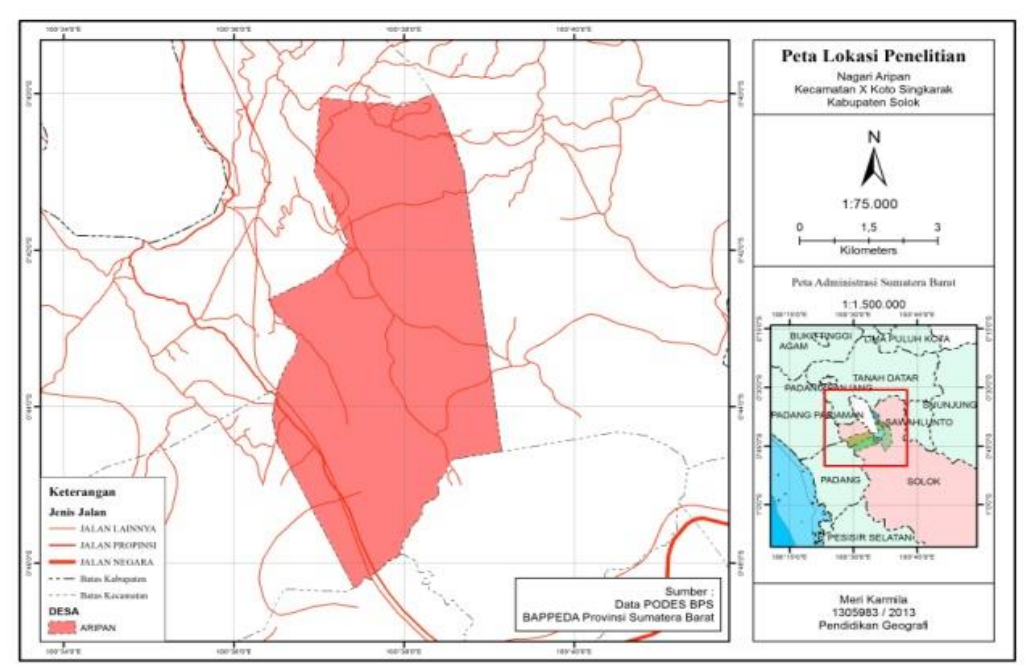

Gambar 1. Peta Lokasi Penelitian

Populasi dan sampel penelitian ini adalah Menurut Arikunto (2006), populasi adalah keseluruhan objek penelitian. Populasi yang berada di Nagari Aripan Kecamatan X Koto Singkarak Kabupaten Solok yaitu terdiri dari 3 jorong, yaitu Jorong Data Tampunik, Jorong Data Bungo, Jorong Pintu Rayo .

Teknik pengambilan sampel dalam penelitian ini adalah Total Sampling. Total Sampling adalah teknik pengambilan sampel dimana jumlah sampel sama dengan populasi (Sugiyono 2007). Alasan mengambil total sampling karena menurut Sugiyono (2007) jumlah populasi yang kurang dari 100 seluruh populasi dijadikan sampel penelitian semuanya. Sampel yang diambil dari penelitian ini adalah 32 orang.

Teknik pengumpul data dalam penelitian ini adalah dari data primer dan data sekunder. Instrumen penelitian menggunakan angket yang disebar kepada kuisioner.
Untuk menganalisis penelitian ini secara deskriptif, maka digunakan analisis statistik deskriptif berupa formula persentase yang dikemukakan oleh Arikunto (2006).

$$
p=\frac{\mathrm{f}}{n} \times 100 \%
$$

Keterangan :

$\mathrm{P}=$ Persentase

$\mathrm{f}=$ Frekuensi

$\mathrm{n}=$ Jumlah Responden

\section{HASIL PENELITIAN DAN PEMBAHASAN}

Lahan yang dikuasai oleh rumah tangga tani dapat digolongkan petani kecil yang memiliki lahan kurang dari 0,5 petani cukupan memiliki lahan 0,5 1,0 $\mathrm{Ha}$, petani besar memiliki lahan diatas 1,0 Ha. Luas Penggunaan Lahan Responden, besarnya penggunaan lahan pertanian sangat mempengaruhi pendapatan pertanian dapat dilihat dalam tabel 2 berikut : 
Tabel 2. Luas Lahan Responden

\begin{tabular}{|c|c|c|c|}
\hline No & Luas Lahan Pertanian (ha) & Frekuensi & Persentase (\%) \\
\hline 1 & $<0,5$ & 6 & 18,75 \\
\hline 2 & $0,5-<1,5$ & 19 & 59,37 \\
\hline 3 & $1,5-<2,5$ & 5 & 15,63 \\
\hline 4 & $\geq 2,5$ & 2 & 6,25 \\
\hline \multicolumn{2}{|c|}{ Jumlah } & 32 & 100 \\
\hline
\end{tabular}

Sumber: Pengolahan Data Primer 2018

Tabel 2 di atas menunjukkan bahwa luas lahan yang dimiliki oleh responden terbesar antara $0,5-<1,5 \mathrm{Ha}$ yaitu sebesar 19 responden atau $59,37 \%$. Luas lahan ini dipergunakan responden dalam kegiatan usaha tani buah naga yang merupakan lahan pemberian orang tua atau diwariskan secara turun temurun.

\section{Biaya Produksi Usaha Tani Buah Naga}

Biaya produksi dari usaha tani buah naga adalah biaya yang dikeluarkan pada saat pelaksanaan usaha tani buah naga dilakukan. Biaya produksi dari usaha tani buah naga dapat dilihat dalam tabel 3 berikut:

Tabel 3. Biaya Produksi Dari Usaha Tani Buah Naga

\begin{tabular}{|c|c|c|c|}
\hline No & Biaya Produksi (Rp) & Frekuensi & Persentase (\%) \\
\hline 1 & $<500.000$ & 19 & 59,38 \\
\hline 2 & $500.000-1.000 .000$ & 12 & 37,5 \\
\hline 3 & $>1.000 .000$ & 1 & 37,5 \\
\hline \multicolumn{2}{|l}{ Jumlah } & 32 & 100 \\
\hline
\end{tabular}

Sumber: Pengolahan Data Primer 2018

Tabel 3 di atas menunjukkan bahwa rata-rata biaya produksi yang digunakan responden antara $<500.000$ yaitu sebanyak 19 responden atau $59,38 \%$.

Biaya yang dikeluarkan oleh petani responden antara lain :

a. Modal

Modal adalah modal yang sifatnya tidak terbatas sehingga jika perusahaan mendapatkan modal ini, perusahaan dapat berkembang dengan cepat. Seperti contohnya adalah investasi dan pinjaman dari bank walaupun jumlahnya tidak terbatas, untuk mendapatkan modal eksternal ini biasanya reputasi perusahaan adalah hal yang akan dipertimbangkan oleh pihak eksternal sebelum mereka memberikan modalnya kepada perusahaan.

b. Bibit atau benih

Pemilihan bibit atau benih merupakan hal yang paling awal daripada usaha tani mencapai produksi. yang dimaksud dengan bibit atau benih adalah biji yang diperlukan dalam pengembangan usaha tani.

\section{c. Pupuk}

Agar tanaman dapat tumbuh dengan baik diperlukan makanan yang cukup. Makanan itu dapat diberikan melalui pemupukan. Bila salah satu 
unsur hara tidak tersedia dalam jumlah yang cukup maka pertumbuhan bibit menjadi tidak normal. Walaupun pemberian pupuk, pemupukan yang berlebihan dapat mengalami kamatian bagi tanaman.

\section{d. Batang penyangga tanaman}

Batang penyangga tanaman yang dimaksud disini adalah penegak untuk tanaman buah naga yang berfungsi untuk pertumbuhan tanaman. penegak untuk tanaman ini ada 2 yaitu yang terdiri dari beton yang dibuat sendiri oleh petani menggunakan semen dan ada juga penegak tanaman menggunakan batang pohon yang sudah dipotong-potong sesuai dengan kebutuhan tanaman.

\section{Penjualan Hasil Usaha Tani Buah Naga}

penjualan hasil panen buah naga adalah penjualan yang dilakukan untuk menghasilkan hasil pendapatan dari usaha para petani buah naga dalam bentuk berupa uang yang dimana penjualan tersebut dapat dilakukan dengan cara menjual langsung ke agennya yaitu orang yang menggambil langsung hasil panen ke perkebunan atau dijual ke pasar terdekat. Cara penjualan petani tersebut dapat dilihat pada tabel 4 dibawah ini :

Tabel 4. Penjualan Hasil Usaha Tani Buah Naga

\begin{tabular}{|c|l|c|c|}
\hline No & Penjualan Hasil Panen & Frekuensi & Persentase (\%) \\
\hline 1 & Jual Melalui Agen & 3 & 9,38 \\
\hline 2 & Jual Ke Pasar & 29 & 90,62 \\
\hline \multicolumn{2}{|l|}{ Jumlah } & 32 & 100 \\
\hline
\end{tabular}

\section{Sumber: Pengolahan Data Primer 2018}

Tabel 4 di atas menunjukkan bahwa penjualan hasil dari usasa tani buah naga responden banyak dilakukan dengan cara menjual langsung ke pasar yaitu sebanyak 29 responden atau $90,62 \%$.

\section{Pendapatan dari Usaha Tani Buah Naga}

Pendapatan dari usaha tani buah naga dapat dilihat dalam tabel 5 berikut ini :

Tabel 5. Pendapatan Usaha Tani Buah Naga

\begin{tabular}{|c|c|c|c|}
\hline No & Pendapatan (Rp) & Frekuensi & Persentase (\%) \\
\hline 1 & $<1.000 .000$ & 7 & 21,87 \\
\hline 2 & $1.000 .000-2.000 .000$ & 18 & 56,26 \\
\hline 3 & $>2.000 .000$ & 7 & 21,87 \\
\hline \multicolumn{2}{|c}{ Jumlah } & 32 & 100 \\
\hline
\end{tabular}

Sumber: Pengolahan Data Primer 2018

Tabel 5 di atas menunjukkan bahwa rata-rata pendapatan responden dari hasil usaha tani buah naga antara 1.000 .000 - 2.000.000 yaitu sebanyak 18 responden atau $56,26 \%$.

\section{Pendapatan dari Responden}

Pendapatan dari responden adalah pendapatan yang diperoleh oleh responden di luar usaha tani buah naga. 
Seperti sebagai wiraswasta, pedagang, buruh harian lepas dan lain sebagainya atau mata pencarian pokok responden. lebih jelasnya dapat dilihat dalam tabel 6 berikut ini :

\section{Tabel 6. Pendapatan Keluarga Responden}

\begin{tabular}{|c|c|c|c|}
\hline No & Pendapatan (Rp) & Frekuensi & Persentase (\%) \\
\hline 1 & $<1.000 .000$ & 0 & 0 \\
\hline 2 & $1.000 .000-2.000 .000$ & 28 & 87,5 \\
\hline 3 & $>2.000 .000$ & 4 & 12,5 \\
\hline \multicolumn{2}{|c|}{ Jumlah } & 32 & 100 \\
\hline
\end{tabular}

Sumber: Pengolahan Data Primer 2018

Tabel 6 di atas menunjukkan bahwa rata-rata pendapatan keluarga responden antara 1.000.000 - 2.000.000 yaitu sebanyak 28 responden atau $87,5 \%$.

Perbandingan dari dua pendapatan yang berasal dari usaha tani buah naga dan pendapatan dari keluarga responden menunjukkan bahwa besarnya kontribusi yang diberikan pada pendapatan keluarga.

\section{Total Pendapatan Keluarga}

Total pendapatan keluarga responden dalam penelitian ini adalah seluruh pendapatan yang diterima oleh responden dalam kurun waktu satu bulan dan dinyatakan dalam rupiah. dapat dilihat dari tabel 7 berikut ini

Tabel 7. Total Pendapatan Keluarga

\begin{tabular}{|c|c|c|c|}
\hline No & Pendapatan (Rp) & Frekuensi & Persentase (\%) \\
\hline 1 & $<2.500 .000$ & 5 & 15,62 \\
\hline 2 & $2.500 .000-4.000 .000$ & 17 & 53,13 \\
\hline 3 & $>4.000 .000$ & 10 & 31,25 \\
\hline \multicolumn{2}{|c}{ Jumlah } & 32 & 100 \\
\hline
\end{tabular}

Sumber: Pengolahan Data Primer 2018

Tabel 7 di atas menunjukkan bahwa rata-rata total pendapatan keluarga responden antara 2.500.000 4.000.000 yaitu sebanyak 17 responden atau $53,13 \%$.

\section{Kontribusi dari Usaha Tani Buah Naga Terhadap Total Pendapatan Keluarga Responden}

Kontribusi yang dimaksud dalam penelitian ini adalah sumbangan dari usaha tani buah naga yang dilakukan di daerah penelitian sebanyak
32 responden yang berprofesi sebagai petani buah naga.

Usaha tani buah naga di Nagari Aripan diusahakan oleh para petani untuk memperoleh pendapatan. Selain dari usaha tani buah naga para petani juga memperoleh pendapatan dari usaha selain usaha tani buah naga. Pendapatan rumah tangga dari usaha lain diperoleh dari hasil bekerja sebagai pedagang, wiraswasta, buruh harian lepas, petani dan lain sebagainya baik yang dikerjakan kepala keluarga maupun anggota keluarga. Pendapatan total 
rumah tangga disini dapat dihitung dari pendapatan usaha tani buah naga dan pendapatan keluarga. untuk perhitungan kontribusi dari usaha tani buah naga terhadap pendapatan total menggunakan rumus :

Tabel 8. Kontribusi Usaha Tani Buah Naga Terhadap Pendapatan Keluarga

\begin{tabular}{|c|l|c|c|}
\hline No & Sumber Pendapatan & $\begin{array}{c}\text { Jumlah } \\
\text { Pendapatan } \\
(\mathbf{R p})\end{array}$ & Persentase (\%) \\
\hline 1 & Usaha Tani Buah Naga & 65.030 .000 & 52,81 \\
\hline 2 & Pendapatan Keluarga & 58.100 .000 & 47,19 \\
\hline \multicolumn{2}{|c}{ Jumlah } & 123.130 .000 & 100 \\
\hline
\end{tabular}

Sumber: Pengolahan Data Primer 2018

Tabel 8 di atas menunjukkan bahwa rata-rata kontribusi usaha tani buah naga responden antara 65.030.000 atau $52,81 \%$.

Berdasarkan hasil penelitian kontribusi usaha tani buah naga terhadap tingkat pendapatan keluarga di Nagari Aripan Kecamatan X Koto Singkarak Kabupaten Solok diperoleh keterangan sebagian besar petani buah naga hasil dari usaha tani buah naga tersebut mampu mencukupi kebutuhan keluarga. Kebanyakan petani buah naga menjual hasil pertaniannya ke pasar dalam bentuk buah tanpa dikemas bagus-bagus. Hasil penelitian menjelaskan usaha tani buah naga merupakan usaha yang mempunyai prospek, keuntungan lebih besar dibandingkan dengan tanaman lain seperti sayur - sayuran.

Faktor Pendorong atau Pendukung dan Faktor Penghambat Terkait Usaha Tani Buah Naga

Nagari Aripan merupakan salah satu nagari di Kabupaten Solok yang masyarakatnya menjalankan usaha tani buah naga. Petani buah naga di Nagari $\frac{\text { Pendapatan Usaha Tani Buah Naga }}{\text { Pendapatan Total Keluarga }} X 100 \%$

Untuk lebih jelasnya besarnya kontribusi usaha tani buah naga dapat dilihat dalam tabel 8 berikut ini:
Aripan awal menjalankan usaha tani buah naga sudah berkisar antara 3 tahun yang lalu. Sekarang banyak petani di Nagari Aripan sudah berpindah pertaniannya dengan menanam buah naga dengan alasan usaha tani tersebut lebih banyak memberikan sumbangan terhadap pendapatan keluarga petani untuk memenuhi kebutuhan dan menjaga kelangsungan hidup mereka dibandingkan dengan kegiatanya dibidang selain pertanian buah naga. Namun tidak semua petani mampu mendapatkan keuntungan yang besar serta mampu mengembangkan usaha tani buah naga tersebut karena setiap usaha itu dapat berkembang atau tidak dipengaruhi oleh faktor yang mendorong dan faktor penghambat yang akan berpengaruh terhadap kemajuan usaha tersebut.

Berdasarkan hasil penelitian di Nagari Aripan Kecamatan X Koto Singkarak Kabupaten Solok dapat diketahui faktor pendorong dan faktor penghambat usaha tani buah naga terhadap pendapatan keluarga adalah 
Faktor pendorong petani buah naga di Nagari Aripan Kecamatan X Koto Singkarak Kabupaten Solok tertarik untuk menjalankan usaha tani buah naga, antara lain : Memiliki lahan yang luas, harga yang tinggi di pasaran, banyaknya tenaga kerja di Nagari Aripan

Faktor penghambat yang dialami petani buah naga di Nagari Aripan Kecamatan X Koto Singkarak Kabupaten Solok dalam menjalankan usaha tani buah naga, antara lain : Modal usaha masih terbatas, keterbatasan pengetahuan tentang budidaya tanaman buah naga karena rendahnya tingkat pendidikan yang dimiliki petani, kurangnya informasi budidaya buah naga dari Dinas Pertanian.

Berdasarkan penjelasan di atas dapat disimpulkan bahwa usaha tani buah naga memberikan kontribusi lebih dari separuhnya dibandingan dengan usaha lain yaitu sebesar 52,81\%, jadi usaha tani ini sangat cocok untuk dikembangkan di nagari penelitian yaitu di Nagari Aripan Kecamatan X Koto Singkarak Kabupaten Solok.

\section{PENUTUP}

\section{Kesimpulan}

Faktor pendukung atau pendorong yaitu selain faktor inti berupa iklim dan lahan yang luas, ada faktor lain yang mendorong petani buah naga di Nagari Aripan Kecamatan X Koto Singkarak Kabupaten Solok tertarik untuk menjalankan usaha tani buah naga, antara lain adalah harganya sangat tinggi dipasaran dan tenaga kerja mudah diperoleh di Nagari Aripan.

\section{Saran}

Bagi pemerintah diperlukannya adanya penyuluhan dalam kegiatan pemeliharaan dan pemberantasan hama dan penyakit pada tanaman buah naga. sehingga ilmu pengetahuan tentang usaha tani buah naga ini dapat diterapkan secara langsung oleh petani, bagi petani buah naga diperlukannya mempelajari tentang budidaya tanaman buah naga melalui pembelian buku tentang budidaya tanaman buah naga dan mengikuti perkembangan teknologi yang digunakan dalam pengembangan usaha tani buah naga dan juga perawatan tanaman buah naga yang intensif untuk menghadapi cuaca yang tidak menentu.

\section{DAFTAR PUSTAKA}

Arikunto, Suharsimi (2006). Prosedur Penelitian, Rineka Cipta

Badan Pusat Statistik (2017).

Kabupaten Solok Dalam Angka 2017. Solok: BPS

Bishop, CE dan Taussan, WD (1979).

Pengantar Analisa Pertanian, Jakarta ; Mutiara

Midgley (2000). Statistik

Kesejahteraan Rumah Tangga

2000, Metode dan Analisis,

Jakarta ; BPS

Mubyarto (1983). Politik Pertanian dan

Pembangunan Pedesaan,

Jakarta ; Sinar Harapan

Mubyarto (1986). Pengantar Ekonomi

Pertanian, Jakarta ; LP3ES

Sugiyono (2007). Metode Penelitian

Kuantitatif dan Kualitatif dan

$R \& D$.Bandung : ALFABETA 